\title{
Characterization and germination of chasmogamous and basal axillary cleistogamous florets of Texas wintergrass
}

\author{
C.A. CALL AND B.O. SPOONTS
}

\section{Abotract}

Texas winteryrass (Stipa leucotricha Trin. \& Rupr.) is an important cool-sesson, perennial forage grass in Tezas. Seed handling problems and a limited knowledge of germination and establishment requirements have severely limited its use in revezetation prozrams. This study was designed to characterize floret morpholosy and investigate the eficets of different temperature $X$ water potential regimes on germination responses of chnsmozamous and basal axillary cleistogamous florets from 2 Texas wintergrass populations in central Texas. Germination responses were evaluated at polyethylene elycol-induced water potentials of $0,-0.25,-0.50$, -0.75 , and $-1.0 \mathrm{MPa}$ under alternating temperature regimes of $10 / 20,15 / 25$, and $20 / 30^{\circ} \mathrm{C}$ in controlled environment chambers. Awns contributed most to the welght of chasmogamous forets, while caryopses contributed most to the welght of cleistogamous forets. Clebtogamous forets generally had higher cumulative germination percentages and slower germination rates than chasmogamous florets in the various temperature $X$ water potential refimes. Cumulative germination percentages of both floret types were greatest at substrate water potentials of 0 and $-0.25 \mathrm{MPa}$ in the $10 / 20^{\circ} \mathrm{C}$ temperature rejime, and mean germination times were moat rapid at the $0 \mathrm{MPa}$ substrate water potential in the $15 / 25^{\circ} \mathrm{C}$ tempenture regime. Based upon seasonal temperature and molature condition in central Texas, germination from natural seed banks or artificial seedings should occur primarily between late September and mid-November, and occasionally from December through February during mild winters.

Key Words: Stpa leucotricha, regenerative stratezy, temperature streas, water stress, viability

Texas wintergrass (Stipa leucotricha Trin. and Rupr.) is an important cool-season grass on rangelands in the Blackland Prairic, Rolling Plains, Edwards Plateau, Rio Grande Plains, and Coastal Plains regions of Texas (Gould 1975). Seed handling problems (associated with awn length) and a limited knowledge of germination and establishment requirements have severely limited its use in revegetation programs (Cardwell 1949, Herrero 1955). This species is one of the few native perennial grasses providing palatable, nutritious forage during winter months, and it has the ability to persist under conditions of disturbance and frequent defoliation (Cardwell 1949, Dyksterhuis 1945). Persistence has been attributed to the production of basal axillary cleistogamous florets (closed, obligately self-fertilized flowers) enclosed in leaf sheaths at the base of the culm (Dyksterhuis 1945). Advantages of this type of cleistogamy include: early floret production under periods of stress or before early termination of plant growth; the protection afforded by the plant base against environmental catastrophes or herbivory; and the placement of florets in the microhab-

\footnotetext{
Authors are assistant professor, Department of Range Science, Utah State University, Logan 84322-5230; and sales representative, American Excelsior Company, Houston, Texas 77055. At time of the research, Call was assistant professor and Spoonts was graduate rescarch assistant, Department of Range Science, Texas A\&M University, College Station 77843.

Published with approval of the Director, Texas Agricultural Experiment Station, as TA-22064.

Manuscript accepted 1 August 1988.
}

itat of the parent plant, providing protection from the risks of random dispersal and seedling establishment (Campbell et al. 1983). Under heavy grazing, chasmogamous florets (open, potentially outcrossed flowers) on aerial panicles may be eaten or damaged, thus subterranean cleistogamous florets would be the primary means of providing progeny for stand maintenance.

Limited information is available on the germination requirements of chasmogamous florets of Texas wintergrass, and no germination information has been reported for basal axillary cleistogamous florets of this amphicarpic species. Herrero (1955) used several pre-imbibition treatments to try to overcome mechanical and/or physiological dormancy mechanisms associated with chasmogamous florets. Andersen (1963) enhanced germination by removing the lemma and palea from the caryopses of chasmogamous florets. More recently, Fowler (1986) partially characterized microsite requirements for germination of chasmogamous florets in field-collected soil in a greenhouse under different watering regimes and soil surface conditions. These germination studies, however, have not simulated the range of temperature and moisture conditions to which florets are exposed throughout the growing season in central Texas.

The objectives of this study were to characterize floret morphology and investigate the effects of different temperature $X$ water potential regimes on germination responses of chasmogamous and basal axillary cleistogamous florets from different populations of Texas wintergrass in the Blackland Prairie region of Texas.

\section{Materials and Methods}

While chasmogamy and cleistogamy properly refer to flowers, these terms have been applied to spikelets and florets and by descent to caryopses (Campbell et al. 1983). Propagules used in other studies have been referred to as spikelets. Propagules used in this study will be referred to as florets (lemma and palea with enclosed flower or caryopsis) because solitary, basal axillary, cleistogamous "spikelets" of Texas wintergrass do not have glumes (Hitchcock 1971), and one-flowered, chasmogamous "spikelets" on aerial panicles separate above the glumes at maturity (Andersen 1963).

Chasmogamous and basal axillary cleistogamous florets of Texas wintergrass were collected from 2 populations on native Blackland Prairie sites near Caldwell and McGregor, Texas in May and June 1985. The Caldwell site is a heavily grazed pasture on a $3 \%$ slope with Texas wintergrass dispersed throughout low areas. The soil is a Dimebox clay (fine, montmorillonitic, thermic Udic Pellustert) with a pH of 7.0 and low $N\left(1.0 \mathrm{mg} \mathrm{kg}^{-1}\right)$ and $P(1.0$ $\mathrm{mg} \mathrm{kg}^{-1}$ ) levels. Average annual precipitation is $977 \mathrm{~mm}$, which occurs in a bimodal pattern with peaks in April through June and September through October. The McGregor site $(130 \mathrm{~km}$ north of the Caldwell site) is a heavily grazed pasture on bottomland. The soil is a Houston black clay (fine, montmorillonitic, thermic Udic Pellustert) with a pH of 8.2 and higher $N\left(2.0 \mathrm{mg} \mathrm{kg}^{-1}\right)$ and $P(12 \mathrm{mg}$ $\mathrm{kg}^{-1}$ ) levels than the Caldwell site. Average annual precipitation is $844 \mathrm{~mm}$ with peaks in April through May and September through November. 
Table 1. Length, weight, and percent by welght of structural components of chasmogamous (CH) and cleistogamous (CL) florests from populations of Texas wintergrass near Caldwell and Mcerezor, Texas.

\begin{tabular}{|c|c|c|c|c|c|c|c|}
\hline \multirow[b]{2}{*}{ Population } & \multirow[b]{2}{*}{ Floret component } & \multicolumn{2}{|c|}{ Length (mm) } & \multicolumn{2}{|c|}{ Weight (mg) } & \multicolumn{2}{|c|}{ Floret wt. (\%) } \\
\hline & & $\mathbf{C H}$ & CL & $\mathrm{CH}$ & CL & $\mathbf{C H}$ & CL \\
\hline Caldwell & $\begin{array}{l}\text { Lemma/palea/callus } \\
\text { Caryopsis } \\
\text { Awn } \\
\text { Floret }\end{array}$ & $\begin{array}{l}10.1 \pm 0.8 \\
(8.5 \pm 0.8)^{2} \\
63.8 \pm 6.8 \\
73.9 \pm 7.0\end{array}$ & $\begin{array}{l}6.5 \pm 0.9 \\
(5.8 \pm 0.5)^{2} \\
3.5 \pm 1.8 \\
10.0 \pm 2.2\end{array}$ & $\begin{array}{r}3.3 \pm 0.3 \\
4.8 \pm 1.2 \\
7.0 \pm 2.0 \\
15.1 \pm 3.0\end{array}$ & $\begin{array}{l}0.6 \pm 0.1 \\
3.0 \pm 0.5 \\
0.3 \pm 0.1 \\
3.9 \pm 0.5\end{array}$ & $\begin{array}{l}21.8 \\
31.8 \\
46.4\end{array}$ & $\begin{array}{r}15.4 \\
76.9 \\
7.7\end{array}$ \\
\hline McGregor & $\begin{array}{l}\text { Lemma/palea/callus } \\
\text { Caryopsis } \\
\text { Awn } \\
\text { Floret }\end{array}$ & $\begin{array}{l}9.7 \pm 0.9 \\
(8.3 \pm 0.7)^{2} \\
56.5 \pm 5.3 \\
66.2 \pm 5.8\end{array}$ & $\begin{array}{l}6.1 \pm 0.7 \\
(5.4 \pm 0.5)^{2} \\
3.2 \pm 1.3 \\
9.3 \pm 1.9\end{array}$ & $\begin{array}{r}2.9 \pm 0.3 \\
4.1 \pm 0.9 \\
6.8 \pm 1.7 \\
13.8 \pm 2.8\end{array}$ & $\begin{array}{l}0.5 \pm 0.1 \\
2.6 \pm 0.5 \\
0.3 \pm 0.1 \\
3.6 \pm 0.4\end{array}$ & $\begin{array}{l}21.0 \\
29.8 \\
49.2\end{array}$ & $\begin{array}{r}19.5 \\
72.2 \\
8.3\end{array}$ \\
\hline
\end{tabular}

IMean value $\pm \mathrm{SD}$.

'Length of caryopsis extracted from lemma/palea/callus complex.

Chasmogamous florets were collected from both sites by hand stripping aerial panicles on individual plants. The same plants were then excavated from the sites and taken to the laboratory where cleistogamous florets were extracted from culm bases after removing leaf sheaths. The long awns on chasmogamous florets were removed by hand, and both types of florets were stored for 3 months at $20^{\circ} \mathrm{C}$ and $40 \%$ relative humidity before germination trials. Caryopses were extracted from $\mathbf{2 0 0}$ chasmogamous florets and 200 cleistogamous florets from each population, soaked in distilled water for 24 hours, and placed in a $1 \%$ solution of triphenyl tetrazolium chloride in the dark at $25^{\circ} \mathrm{C}$ for 24 hours to determine viability. Component structures (lemma/palea/callus complex, awn, and caryopsis) of 50 chasmogamous and 50 cleistogamous florets from each population were measured for length and weight. The number of leaf sheaths and culms surrounding cleistogamous florets was quantified by cross-sectioning 25 excavated plants from each population at the base of the crown. Plants were immersed in paraffin before cutting to maintain the integrity of the leaf sheaths and culms.

Lots of 100 chasmogamous florets and 100 cleistogamous florets from each population were placed on one piece of Whatman No. 1 chromatography paper in separate $13 \times 13.5 \times 3.5-\mathrm{cm}$ plastic trays. The chromatography paper was supported by a 5-mm thick piece of polyurethane foam with 5 cotton wicks which extended into a 200-ml reservoir of solution. Solutions had water potentials of $0,-0.25,-0.50$, and -0.75 , and $-1.0 \mathrm{MPa}$, which were derived by mixing 20,000 MW polyethylene glycol(PEG) with distilled water. Solution water potentials were measured by saturating chromatography paper discs (3-mm diam) and placing them into a Wescor Model C-52 psychrometer sample chamber. Readings were recorded with a Wescor HR 33-T microvoltmeter following a 1-min equilibration period and a 5 -sec cooling period. Solution water potentials were measured the day following initial mixing and the day following any adjustments in PEG concentrations to achieve desired water potentials. Trays were wrapped with clear polyethylene film to reduce evaporation and stabilize relative humidity.

Trays were placed in controlled environment chambers with night / day temperature regimes of $10 / 20,15 / 25$, and $20 / 30^{\circ} \mathrm{C}$ and 12-hour photoperiods. During the day period, a light intensity of $450 \mu \mathrm{mol} \mathrm{m}^{-2} \mathrm{sec}^{-1}$ was maintained at tray level. Germination was evaluated every other day over a 29-day period. The caryopsis, enclosed in the lemma and palea of the floret, was considered to have germinated when the coleoptile had emerged and radicle length was greater than or equal to $5 \mathrm{~mm}$ (Copeland 1978). Germination rates were estimated by calculating the mean time in days taken for nondormant viable caryopses to germinate (Ellis and Roberts 1978). The mean germination time (MGT) was calculated as follows:

$$
\text { MGT }=\frac{\sum(D n)}{\sum \text { n }}
$$

where $\mathrm{n}$ is the number of caryopses which germinate on day $\mathrm{D}$, and $D$ is the number of days counted from the beginning of the germination test.

The germination experiment was arranged in a completely randomized design with 3 replications (trays) per treatment. The entire experiment was repeated, and data from both trials were combined and analyzed by analysis of variance and quadratic response surface procedures $(P<0.05)$ (Evans et al. 1982, Ray 1982). Germination data were transformed with an arcsin transformation before statistical analysis.

\section{Results}

\section{Floret Characterization}

Basal axillary cleistogamous florets, found in $92 \%$ of the crosssectioned culms for the Caldwell population and $85 \%$ of the culms from the McGregor population, were enveloped by 1 to 4 leaf sheaths at the base of the culm and surrounded by 1 to as many as 7 culms of the same parent plant. Component structures of cleistogamous florets were greatly reduced in length and weight relative to those of chasmogamous florets for both populations (Table 1). Cleistogamous caryopses were smaller than chasmogamous caryopses, but when compared on a relative weight basis, cleistogamous caryopses comprised 42 to $45 \%$ more of the total floret weight for the 2 populations. Awns accounted for greater than $45 \%$ of the total weight of chasmogamous florets for both populations.

\section{Germination Responses}

Caryopses from chasmogamous florets of both populations had a mean viability of $60 \%$, while caryopses from cleistogamous florets of the Caldwell and McGregor populations had mean viabilities of 75 and $72 \%$, respectively.

Cumulative germination of chasmogamous and cleistogamous florets for both populations was greatest at the $0 \mathrm{MPa}$ water potential in the $10 / 20^{\circ} \mathrm{C}$ temperature regime, and generally decreased as substrate water potential decreased and temperature increased (Table 1). With the exception of chasmogamous florets from the McGregor population, germination was reduced significantly $(P<0.05)$ when substrate water potentials decreased from -0.50 to $-0.75 \mathrm{MPa}$ and from -0.75 to $-1.0 \mathrm{MPa}$ in the $10 / 20$ and $15 / 25^{\circ} \mathrm{C}$ temperature regimes. Cumulative germination of chasmogamous florets from the McGregor population was significantly $(P<0.05)$ lower than that of chasmogamous florets from the Caldwell population at more favorable water potentials in the $10 / 20$ and $15 / 25^{\circ} \mathrm{C}$ temperature regimes. Similarly, germination of cleistogamous florets from the McGregor population was slightly lower than that of cleistogamous florets from the Caldwell 
Table 2. Eotimated cumulative germination (\%) for chasmogamous (CH) and cleistogamous (CL) florests from populations of Teras wintergrass near Caldwell and MeGrezor, Texas in relation to various substrate water potentials and alternating temperature regimes.1

\begin{tabular}{|c|c|c|c|c|c|c|c|}
\hline \multirow[b]{2}{*}{ Population } & \multirow{2}{*}{$\begin{array}{l}\text { Floret } \\
\text { type }\end{array}$} & \multirow{2}{*}{$\begin{array}{l}\text { Temperature } \\
\text { regime }\left({ }^{\circ} \mathrm{C}\right)^{2}\end{array}$} & \multicolumn{5}{|c|}{ Water potential (MPa) } \\
\hline & & & $\mathbf{0}$ & -0.25 & -0.50 & -0.75 & -1.0 \\
\hline \multirow[t]{2}{*}{ Caldwell } & $\mathbf{C H}$ & $\begin{array}{l}10 / 20 \\
15 / 25 \\
20 / 30\end{array}$ & $\begin{array}{l}59(10) \\
39(8) \\
12(10)\end{array}$ & $\begin{array}{l}56(7) \\
46(7) \\
22(7)\end{array}$ & $\begin{array}{l}\text { tion (\%) } \\
48(7) \\
42(7) \\
22(7)\end{array}$ & $\begin{array}{l}32(7) \\
29(7) \\
12(7)\end{array}$ & $\begin{array}{l}6(10) \\
6(8) \\
0(10)\end{array}$ \\
\hline & CL & $\begin{array}{l}10 / 20 \\
15 / 25 \\
20 / 30\end{array}$ & $\begin{array}{l}63(9) \\
52(9) \\
23(9)\end{array}$ & $\begin{array}{l}57(6) \\
49(5) \\
25(6)\end{array}$ & $\begin{array}{l}44(6) \\
41(6) \\
21(6)\end{array}$ & $\begin{array}{l}26(6) \\
28(5) \\
11(6)\end{array}$ & $\begin{array}{l}3(8) \\
8(7) \\
1(8)\end{array}$ \\
\hline \multirow[t]{2}{*}{ McGregor } & $\mathrm{CH}$ & $\begin{array}{l}10 / 20 \\
15 / 25 \\
20 / 30\end{array}$ & $\begin{array}{l}21(12) \\
20(10) \\
15(12)\end{array}$ & $\begin{array}{l}21(7) \\
21(7) \\
17(8)\end{array}$ & $\begin{array}{l}19(8) \\
20(8) \\
14(8)\end{array}$ & $\begin{array}{l}14(8) \\
16(7) \\
12(7)\end{array}$ & $\begin{array}{c}6(11) \\
10(10) \\
8(11)\end{array}$ \\
\hline & CL & $\begin{array}{l}10 / 20 \\
15 / 25 \\
20 / 30\end{array}$ & $\begin{array}{l}57(10) \\
41(9) \\
18(9)\end{array}$ & $\begin{array}{l}54(7) \\
43(6) \\
21(5)\end{array}$ & $\begin{array}{l}38(6) \\
36(7) \\
16(6)\end{array}$ & $\begin{array}{r}22(7) \\
21(6) \\
9(6)\end{array}$ & $\begin{array}{l}4(8) \\
6(8) \\
1(9)\end{array}$ \\
\hline
\end{tabular}

${ }^{1}$ Germination estimates derived by quadratic response surface analysis; values in parentheses following means are one-half the calculated confidence intervals ( $P<0.05$ ). 212 hour night/ 12 hour day temperatures.

population at water potentials of 0 to $-0.75 \mathrm{MPa}$ in all 3 temperature regimes. Cleistogamous florets from both populations had higher cumulative germination percentages than chasmogamous florets in most of the temperature regime $X$ water potential combinations.

Mean germination time was shortest for chasmogamous and cleistogamous florets from both populations at the 0 and -0.25 $\mathrm{MPa}$ levels in the $15 / 25$ and $20 / 30^{\circ} \mathrm{C}$ temperature regimes, and increased by 1 to 6 days (depending on water potential level) as temperatures declined from $15 / 25$ to $10 / 20^{\circ} \mathrm{C}$ (Table 3). With the exception of chasmogamous florets from the McGregor population, mean germination time increased 5 to 9 days as substrate water potentials decreased from 0 to $-1.0 \mathrm{MPa}$ in all 3 temperature regimes. Mean germination time of cleistogamous florets from the McGregor population was 1 to 2 days longer than that of cleistogamous florets from the Caldwell population at the various water potential $\times$ temperature regime combinations. Mean germination time values for cleistogamous florets from both populations were 1 to 5 days longer than those of chasmogamous florets at most of the water potential $\times$ temperature regime combinations.

\section{Discussion}

\section{Floret Characterization}

Reductions in the size of caryopsis, lemma/palea/callus complex, and awn of cleistogamous florets from the 2 populations may be attributable to adaptations for enclosure in basal leaf sheaths and to relaxed selection for dispersal mechanisms of chasmogamous florets (Campbell et al. 1983). Long awns facilitate the movement of chasmogamous florets across the soil surface to more distant, favorable microsites (i.e., soil cracks or litter) (Peart 1979), whereas short-awned cleistogamous florets remain in the favorable microenvironment of the parent plant. Long, hygroscopic awns may drill chasmogamous florets into the soil by twisting and straightening when exposed to cycles of dehydration and hydration (Simpson 1952). Retorsely scabrous hairs on the callus end anchor the chasmogamous floret in the soil and counter the force produced by the radicle as it penetrates into the soil (Peart 1979).

The relative allocation of resources to chasmogamous and cleistogamous florets of Texas wintergrass and other amphicarpic grass species is influenced by several interacting environmental factors, including available soil moisture, temperature, nutrient availabil-

Table 3. Estimated germination time (days) for chasmogamous (CH) and cleiatogamous (CL) florests from populations of Texas wintergrass near Caldwell and MeGregor, Texas in relation to various substrate water potentials and alternating temperature regimes.'

\begin{tabular}{|c|c|c|c|c|c|c|c|}
\hline \multirow[b]{2}{*}{ Population } & \multirow{2}{*}{$\begin{array}{c}\text { Floret } \\
\text { type }\end{array}$} & \multirow{2}{*}{$\begin{array}{l}\text { Temperature } \\
\text { regime }\left({ }^{\circ} \mathrm{C}\right)^{2}\end{array}$} & \multicolumn{5}{|c|}{ Water potential (MPa) } \\
\hline & & & $\mathbf{0}$ & -0.25 & -0.50 & -0.75 & -1.0 \\
\hline & & & & -N & ation ti & & \\
\hline \multirow[t]{2}{*}{ Caldwell } & $\mathrm{CH}$ & $\begin{array}{l}10 / 20 \\
15 / 25 \\
20 / 30\end{array}$ & $\begin{array}{l}17(2) \\
15(2) \\
15(2)\end{array}$ & $\begin{array}{l}17(1) \\
15(1) \\
15(1)\end{array}$ & $\begin{array}{l}18(2) \\
16(2) \\
16(2)\end{array}$ & $\begin{array}{l}20(2) \\
18(1) \\
18(2)\end{array}$ & $\begin{array}{r}22(4) \\
22(2) \\
-3\end{array}$ \\
\hline & $\mathbf{C L}$ & $\begin{array}{l}10 / 20 \\
15 / 25 \\
20 / 30\end{array}$ & $\begin{array}{l}19(1) \\
15(1) \\
16(1)\end{array}$ & $\begin{array}{l}18(1) \\
15(1) \\
15(1)\end{array}$ & $\begin{array}{l}19(1) \\
16(1) \\
17(1)\end{array}$ & $\begin{array}{l}22(1) \\
19(1) \\
20(1)\end{array}$ & $\begin{array}{l}26(1) \\
24(1) \\
25(1)\end{array}$ \\
\hline \multirow[t]{2}{*}{ McGregor } & $\mathbf{C H}$ & $\begin{array}{l}10 / 20 \\
15 / 25 \\
20 / 30\end{array}$ & $\begin{array}{l}24(4) \\
18(3) \\
17(4)\end{array}$ & $\begin{array}{l}21(3) \\
16(3) \\
17(3)\end{array}$ & $\begin{array}{l}18(3) \\
16(3) \\
18(3)\end{array}$ & $\begin{array}{l}18(3) \\
17(2) \\
20(4)\end{array}$ & $\begin{array}{l}23(4) \\
20(4) \\
21(4)\end{array}$ \\
\hline & CL & $\begin{array}{l}10 / 20 \\
15 / 25 \\
20 / 30\end{array}$ & $\begin{array}{l}20(2) \\
17(1) \\
17(2)\end{array}$ & $\begin{array}{l}20(1) \\
16(1) \\
17(1)\end{array}$ & $\begin{array}{l}21(2) \\
17(1) \\
18(1)\end{array}$ & $\begin{array}{l}23(2) \\
19(1) \\
21(2)\end{array}$ & $\begin{array}{l}26(1) \\
23(1) \\
26(2)\end{array}$ \\
\hline
\end{tabular}

tMean germination time estimates derived by quadratic response surface analysis; values in parentheses following means are one-half the calculated confidence intervals $(P<0.05)$.

${ }^{2} 12$ hour night / 12 hour day temperatures.

${ }^{3}$ No germination observed during 29-day trial. 
ity, photoperiod, light intensity, plant density, and frequency and intensity of defoliation (Bell and Quinn 1987, Brown 1952, Clay 1983). Under suboptimal growing conditions, a higher proportion of cleistogamous florets may be produced because they have reduced floral parts and presumably cost less to produce than chasmogamous florets (Campbell et al. 1983). In addition to allocating a greater proportion of resources to caryopses than accessory structures, cleistogamous florets of Texas wintergrass are also produced before chasmogamous florets (Dyksterhuis 1945) and thus have earlier access to available resources. Peanutgrass (Amphicarpum purshii), an amphicarpic annual adapted to disturbed areas in the Coastal Plain of eastern North America, has also been shown to allocate resources earlier to subterranean cleistogamous florets than to aerial chasmogamous florets (Cheplick and Quinn 1982).

Differential germination responses of chasmogamous and cleistogamous florets from the 2 populations of Texas wintergrass can be explained, in part, by site environmental conditions and mechanical and physiological dormancy mechanisms. Chasmogamous and cleistogamous florets from the Caldwell population developed under a more favorable moisture regime before collection in late May and early June 1985. The Caldwell and McGregor sites received $1,003 \mathrm{~mm}$ and $777 \mathrm{~mm}$, respectively, during 1984, and $290 \mathrm{~mm}$ and $261 \mathrm{~mm}$, respectively, from January through May 1985. Even under optimal temperature and moisture conditions in the controlled environment, chasmogamous florets from the McGregor population had the lowest cumulative germination in relation to potential viability and the slowest mean germination time of any floret type from the 2 populations. Fowler (1986) observed a similar germination response for chasmogamous florets from a population of Texas wintergrass in the Edwards Plateau region of central Texas where precipitation averages $890 \mathrm{~mm}$ annually. Only $25 \%$ of the viable caryopses germinated in a $16 / 21^{\circ}$ $C$ alternating temperature regime in a controlled environment. Fowler (1986) also observed that stratification (florets wet for 14 days at $5^{\circ} \mathrm{C}$ ) lowered germination slightly, and that scarification (method not indicated) and after-ripening (time length not indicated) did not improve germination, indicating the absence of physiological and/ or mechanical dormancy mechanisms for chasmogamous florets. However, Andersen (1963) removed the lemma and palea from chasmogamous florets of Texas wintergrass and increased cumulative germination to $94 \%$ and hastened germination rate in a $15 / 25^{\circ} \mathrm{C}$ alternating temperature regime in a controlled environment. Significant reductions in cumulative germination in both floret types from the Caldwell and McGregor populations in the $20 / 30^{\circ} \mathrm{C}$ temperature regime support the hypothesis that physiological dormancy mechanisms may reduce early germination of Stipa florets during the hot, dry summer months following dispersal (McAlister 1943, Rogler 1944, Fuloright et al. 1983). Germination in the $20 / 30^{\circ} \mathrm{C}$ temperature regime in the controlled environment may have been higher than that which would occur under field conditions with the same temperature regime, since florets in germination trays were always in contact with a moist substrate and a high relative humidity. Dyksterhuis (1945) observed that Texas wintergrass plants several years of age, such as those used in this study, could have basal axillary cleistogamous florets ranging in age from 1 to 3 years. Therefore, in addition to having priority in resource allocation during development, cleistogamous florets used in this study may have developed under a variety of environmental conditions, and may have had sufficient time to overcome any physiologically imposed dormancy. Chasmogamous florets, especially those from the McGregor population, developed under one set of suboptimal conditions which may have intensified the effect of mechanical and/or physiological dormancy mechanisms.
Germination studies with other amphicarpic species show that chasmogamous and cleistogamous spikelets behave differently. McNamara and Quinn (1977) investigated the germination of aerial chasmogamous spikelets and subterranean cleistogamous spikelets from the same population of peanutgrass in controlled environments with $15 / 25,20 / 30$, and $20 / 35^{\circ} \mathrm{C}$ alternating temperature regimes. Cumulative germination after 21 days ranged from 1 to $43 \%$ for caryopses from chasmogamous spikelets and from 34 to $87 \%$ for caryopses from cleistogamous spikelets. Dobrenz and Beetle (1966) observed no difference in cumulative germination between chasmogamous and cleistogamous spikelets of one-spike oatgrass (Danthonia unispicata) and California oatgrass (D. californica), but found cleistogamous spikelets to have a higher cumulative germination (70\%) than chasmogamous spikelets (33\%) in poverty oatgrass $(D$. spicata). Clay (1983) planted both types of spikelets of poverty oatgrass at a depth of $0.5 \mathrm{~cm}$ in a greenhouse environment $\left(26.6^{\circ} \mathrm{C}\right)$, and observed $35 \%$ germination after 10 days for cleistogamous spikelets compared to $20 \%$ germination after $\mathbf{2 7}$ days for chasmogamous spikelets.

Based upon optimum germination responses (greatest cumulative germination and most rapid mean germination time) and seasonal temperature and moisture availability in the Blackland Prairie region of central Texas (National Oceanographic Atmospheric Administration 1984), germination from natural seedbanks or artificial seedings should occur between late September and mid-November. Relatively high cumulative germination percentages in the $10 / 20^{\circ} \mathrm{C}$ temperature regime indicate that germination could occur December through February during mild winters. Fowler (1986) observed germination of chasmogamous florets in the Edwards Plateau region of central Texas in October and November, and indicated from controlled environment studies that germination could occur in February or March. Dyksterhuis (1945) first observed seedlings from chasmogamous florets and cleistogamous florets in late September and mid-October, respectively, in the northern portion of the Blackland Prairie region. Slower mean germination times for cleistogamous florets may not be detrimental to germination and seedling establishment under field conditions, because of their location in a relatively favorable microenvironment created by the parent plant. When compared to chasmogamous floret germination in an exposed soil environment, the cleistogamous floret in the residue of the parent plant may have more favorable temperature and moisture conditions over a longer period of time.

This study of the component structures, viability, and germination responses of chasmogamous and basal axillary cleistogamous florets from 2 populations of Texas wintergrass in the Blackland Prairie region of central Texas gives an indication of the relative importance of the 2 types of propagules in the maintenance of Texas wintergrass stands under field conditions. Since cleistogamous florets allocate fewer resources to accessory structures and have higher viability and germination percentages than chasmogamous florets, and remain in the favorable microhabitat of the parent plant, seedlings arising from these florets may have a better chance of survival to reproductive age. Self-fertilization and cleistogamy may be largely responsible for the ability of Texas wintergrass to regenerate under continuous heavy grazing pressure. While cleistogamous florets provide for a high probability of local reproductive success, chasmogamous florets, with greater genetic variability and morphological adaptations for dispersal, provide an opportunity for more distant reproductive success.

\section{Literature Cited}

Andersen, A.M. 1963. Germination of seed of Texas needlegrass, Stipa leucotricha. Proc. Assoc. Off. Seed Anal. 53:74-79. 
Bell, T.J., and J.A. Quinn. 1987. Effects of soil moisture and light intensity on the chasmogamous and cleistogamous components of reproductive effort of Dichanthelium clandestinum populations. Can. J. Bot. 65:22432249.

Brown, W.V. 1952. The relation of soil moisture to cleistogamy in Stipa leucotricha. Bot. Gaz. 113:438-444.

Campbell, C.S., J.A. Quinn, G.P. Chepllek, and T.J. Bell. 1983. Cleistogamy in grasses. Ann. Rev. Ecol. Syst. 14:411-441.

Cardwell, W.W. 1949. A study of Texas wintergrass: Effects of height, frequency, and season of clipping upon forage production and the methods of harvesting seed on rangelands. M.S. thesis. Texas A\&M Univ., College Station.

Cheplick, G.P., and J.A. Quinn. 1982. Amphicarpum purshil and the "pessimistic stategy" in amphicarpic annuals with subterranean fruits. Oecologia 52:327-332.

Clay, $\mathbf{K}$. 1983. The differential establishment of seedlings from chasmogamous and cleistogamous flowers in natural populations of the grass Danthonia spicata (L.) Beauv. Oecologia 57:183-185.

Copeland, L.0. (ed.). 1978. Rules for testing seeds. Proc. of the Assoc. Off. Seed Analysts. J. Seed Tech. 3(3).

Dobrenz, A.K., A.A. Beetle. 1966. Cleistogenes in Danthonia J. Range Manage. 19:292-296.

Dyksterhuis, E.J. 1945. Axillary cleistogenes in Stipa leucotricha and their role in nature. Ecology 26:195-199.

Ellis, R.H., and E.H. Roberts. 1978. Towards a rational basis for testing seed quality. p. 605-636. In: P.D. Hebblethwaite (ed), Seed production. Butterworths, London.

Evan, R.A., D.A. Easi, D.N. Book, and J.A. Young. 1982. Quadratic response surface analysis of seed germination trails. Weed Sci. 30:411-416.
Fowler, N.L. 1986. Microsite requirements for germination and establishment of 3 grass species. Amer. Midl. Natur. 115:131-145.

Fulbright, T.E., L.F. Redente, and A.M. Wilson. 1983. Germination requirements of green needlegrass (Stipa viridula Trin.) J. Range Manage. 36:390-394.

Gould, F.W. 1975. The grasses of Texas. Texas A\&M Univ. Press, College Station.

Herrero, F.A. 1955. A study to determine possible methods for increasing the germination of Texas wintergrass (Stipa leucotricha Trin. \& Rupr.). M.S. thesis. Texas A\&M Univ., College Station.

Hitcheock, A.S. 1971. Manual of the grasses of the United States. 2nd Ed. Dover Publ., Inc., New York.

McAlister, D.F. 1943. The effect of maturity on the viability and longevity on the seeds of western range and pasture grasses. J. Amer. Soc. Agron. 35:445-453.

MeNamarn, J., and J.A. Quinn. 1977. Resource allocation and reproduction in populations of Amphicarpum purshii (Gramineae). Amer. J. Bot. 64:17-23.

National Oceanographic Atmospheric Adminiatration. 1984. Climatological data for Texas. United States Dep. Commerce, Washington, D.C.

Peart, M. 1979. Experiments on the biological significance of the morphology of seed-dispersal units in grasses. J. Ecol. 67:843-863.

Ray, A.A. (ed.). 1982. SAS user's guide: Statistics. SAS Institute, Cary, N.C.

Rogler, G.A. 1944. Relation of seed dormancy of green needlegrass (Stipa viridula Trin.) to age and treatment. Agron. J. 52:462-469.

Simpson, M. 1952. Value of the awn in establishing seed of Danthonia penicillata (Labill.) Palisot. New Zeal. J. Sci. Tech. 34:360-364.

A History of the Socloty for Range Management, 1948-1985 by Clinton H. Wasser, Elbert H. Reid, and Arthur D. Smith. Based on the philosophy that any society that does not know its own history is doomed to repeat its mistakes, purchase of this publication is a must for all leaders and would-be-leaders of the Society. Besides that, it's just plain interesting to read. You may even find that your own name "has gone down in history!" 76 pages $81 / 2$ by 11 , illustrated, indexed, soft cover, $\$ 10.00$ US.

Quotable Range Quotes II compiled by E. William Anderson. This second edition provides 366 "quotable quotes" from JRM, Rangeman's News, Rangeman's Journal, and Rangelands, covering the period from 1948 to 1982 . A Reference Cited chart identifies the speaker, title of the article, and published source. Ideal for those who speak and write about range management frequently. 56 pages, $81 / 2$ by 11 , spiral bound, soft cover, $\$ 7.50$.

These books and many more on range management and related topics are available from the Soclety for Range Management, 1839 York St., Denver, CO 80206. Telephone: (303)355-7070. 